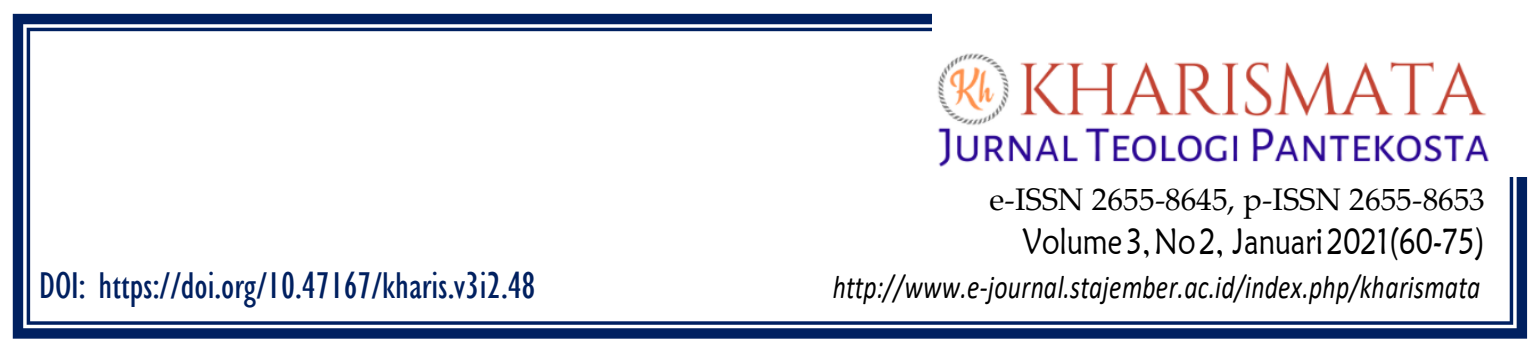

\title{
Upaya Meningkatkan Etos Kerja Jemaat melalui Pengajaran Hakikat Kerja Menurut Kolose 3:22-24
}

\author{
Innawati Teddywono \\ Institut Injil Indonesia, Malang, Jawa Timur \\ innawati.t@gmail.com
}

\begin{abstract}
The Bible teaches about the nature of work as an activity that is meaningful for humans and others. That is why Christian workers must have a biblical work ethic in the world of work. This research uses a quantitative approach with a survey method. The research objective was to determine the level of understanding of the GPdI Wlingi congregation in Blitar regarding the nature of work according to Colossians 3:22-24 and the work ethic. This study found the magnitude of the influence of teaching about the nature of work according to Colossians 3: 22-24 on work variables among the GPdI Wlingi congregation, Blitar was 18.5\%, while other causes explained the remaining $81.5 \%$ outside of this research model. It means that teaching about the nature of work, according to Colossians 3:22-24, must be taught and implemented by the church to improve its congregation's work ethic.
\end{abstract}

Keywords: Colossians; congregation; nature of work; teaching; work ethic

\begin{abstract}
Abstrak. Alkitab memberikan pengajaran tentang hakikat kerja sebagai suatu aktivitas yang sangat bermakna bagi manusia dan sesamanya. Itulah sebabnya, pekerja Kristen harus memiliki etos kerja yang alkitabiah di tengah dunia kerja. Penelitian ini menggunakan pendekatan kuantitatif dengan metode survei. Tujuan penelitian hendak mengetahui seberapa besar tingkat pemahaman jemaat GPdI Wlingi, Blitar, mengenai hakikat kerja menurut Kolose 3:22-24, dan terhadap etos kerja. Penelitian ini menemukan besarnya pengaruh ajaran tentang hakikat kerja menurut Kolose 3:22-24 terhadap variabel kerja di kalangan jemaat GPdI Wlingi, Blitar adalah 18,5\%, sedangkan sisanya sebesar $81,5 \%$ dijelaskan oleh sebab-sebab lain di luar model penelitian ini. Ini berarti pengajaran tentang hakikat kerja menurut Kolose 3:22-24 harus diajarkan dan diimplementasikan oleh gereja untuk meningkatkan etos kerja jemaatnya.
\end{abstract}

Kata kunci: etos kerja; hakikat kerja; jemaat; Kolose; pengajaran

\section{PENDAHULUAN}

Etos kerja menentukan kemajuan suatu bangsa, demikian juga dalam meraih kesuksesan dalam perusahaan. Etos kerja dari anak buah mendukung keberhasilan suatu organisasi. Etos kerja terkait erat dengan kepribadian dan karakter seseorang. ${ }^{1}$ Setiap manusia memiliki nilai-nilai dalam dirinya yang akan tercermin pada sikap hidupnya. Respon dari dalam diri seseorang terhadap tuntutan dunia kerja akan banyak mempengaruhi etos kerja dirinya.

\footnotetext{
${ }^{1}$ Mochammad Nadjib, “Agama, Etika Dan Etos Kerja Dalam Aktivitas Ekonomi Masyarakat Nelayan Jawa," Jurnal Ekonomi dan Pembangunan (2013).
} 
Melalui hasil wawancara dengan gembala GPdI Wlingi, peneliti menemukan berbagai masalah yang timbul di jemaat gereja, antara lain adanya pengangguran, pendapatan keluarga kurang dan sebagian lain pas-pasan, orang melakukan tindakan kurang jujur di pekerjaan, meminta pertolongan ke paranormal (melakukan tindakan pemujaan berhala; misal memiliki jimat, meminta pelaris untuk dagangannya), tidak puas dan bersungut-sungut tentang pekerjaannya; lebih jauh lagi karena lebih mementingkan tuntutan hidup untuk mencari nafkah, ada jemaat yang undur atau meninggalkan Tuhan, semuanya itu bermuara pada permasalahan usaha dalam dunia kerja dan memenuhi ekonomi keluarga. Dalam perspektif Kristen dunia kerja adalah implementasi tanggungjawab iman seseorang terhadap Tuhan dan sesama. Dunia kerja adalah suatu ladang pelayanan. Etika Kristen dalam dunia kerja harus dilaksanakan sesuai Firman Tuhan. ${ }^{2}$

Menurut Laily Dwi Arsyianti, kemiskinan merupakan konsep multidimensi, kemiskinan tidak hanya terkait secara ekonomi tetapi juga segi sosial, psikologi, dan spiritual seseorang. ${ }^{3}$ Nur Mualifah menyatakan bahwa kemiskinan adalah kondisi seseorang di mana tidak mampu memenuhi kebutuhan dasarnya sehingga tidak mampu mengembangkan kehidupannya. Penelitiannya menemukan bahwa kemiskinan menyebabkan seseorang kehilangan hak kesejahteraan dalam bidang pangan, sandang dan papan. Kemiskinan menyebabkan seseorang tidak mampu mendapatkan pendidikan yang baik; di mana berdampak pada sulitnya memperoleh pekerjaan yang layak, sehingga akan berdampak dalam memenuhi kebutuhan hidupnya. ${ }^{4}$ Seseorang yang kesulitan dalam memenuhi kebutuhan dasarnya akan memfokuskan pikiran dan perhatiannya pada pemenuhan kebutuhan dasarnya (pangan, sandang, dan papan) tersebut, prioritas utamanya pada pemenuhan kebutuhan jasmani bukan kebutuhan spiritualnya.

Dalam kehidupan seorang manusia, ada banyak kebutuhan yang harus dipenuhi untuk kelangsungan hidupnya. Hikma Nur dalam penelitiannya pada aspek psikologis tokoh utama dalam novel Sepatu Dahlan Karya Krishna Pabichara dengan berdasarkan psikologi humanistik Abraham Maslow mengemukakan bahwa seseorang harus dapat memenuhi setiap kebutuhannya (dalam piramida kebutuhan Abraham Maslow) sebelum ia dapat mengaktualisasikan dirinya. ${ }^{5}$ Kebutuhan yang pertama adalah kebutuhan jasmani, jika kebutuhan ini belum terpenuhi, menurut Maslow belum beranjak ke level kebutuhan berikutnya. Sama seperti yang dialami tokoh utama dalam novel tersebut, seseorang harus melalui tahapan pemenuhan kebutuhan jasmaninya baru kemudian kebutuhan rohaninya.

\footnotetext{
${ }^{2}$ Malik Bambangan, "Perspektif Teologis Terhadap Etika Bisnis Kristen," JURNAL LUXNOS (2019).

${ }^{3}$ Laily Dwi Arsyianti, "Zakat Dan Kemiskinan Multidimensi," Republika Online, 2014.

${ }^{4}$ Nur Mualifah, "Dampak Kemiskinan Terhadap Kesejahteraan Masyarakat Kampung Bumi Raharjo Dalam Prespektif Ekonomi Islam," IAIN METRO (2019).

${ }^{5}$ Hikma Nur, "Aspek Psikologis Tokoh Dalam Novel Sepatu Dahlan Karya Khrisna Pabichara (Kajian Psikologi Humanistik Abraham Maslow)," Jurnal humanika (2015).
} 
Masalah-masalah dunia kerja, berdampak pada pula gereja; kesulitan dalam mencari nafkah untuk memenuhi kebutuhan hidup sehari-hari berimbas pula pada kehidupan rohani seseorang. Ini sesuai dengan teori Abraham Maslow, di mana seseorang yang belum dapat memenuhi kebutuhan hidup di level yang lebih awal, tak akan mencapai level kebutuhan hidup berikutnya. Maslow berasumsi bahwa, manusia adalah mahluk yang memiliki berbagai kebutuhan. Manusia bermotivasi untuk memenuhi kebutuhan-kebutuhan, yang secara universal tersusun menurut tingkat kepentingannya. Kebutuhan-kebutuhan itu adalah, kebutuhan fisik/badan, kebutuhan akan keamanan, kebutuhan bermasyarakat atau kebutuhan sosial, kebutuhan akan harga diri, kebutuhan akan pengakuan diri. ${ }^{6}$ Penelitian Elisa Sari membuktikan bahwa kebutuhan fisiologis sangat dominan berpengaruh pada etos kerja seseorang. ${ }^{7}$

Seseorang yang belum dapat memenuhi kebutuhan jasmaninya, maka sukar atau hampir bisa dikatakan tidak dapat memenuhi kebutuhan rohaninya dengan baik. Kebutuhan jasmani itu dapat dipenuhi seseorang dengan cara bekerja. Seorang pekerja Kristen seharusnya memahami hakikat kerja dan etos kerja yang alkitabiah, yang tertuang dalam Kolose 3:22-24. Penelitian ini bertujuan untuk menemukan: Pertama, seberapa besar tingkat pemahaman jemaat GPdI Wlingi, Blitar mengenai ajaran hakikat kerja menurut Kolose 3:22-24, serta pengaruh terhadap etos kerja jemaat GPdI Wlingi, Blitar.

\section{METODE}

Penelitian ini menggunakan pendekatan kuantitatif dengan metode survei ${ }^{8}$; penelitian dilaksanakan pada populasi besar dan kecil, data yang dianalisis diperoleh dari sampel, sehingga ditemukan kejadian-kejadian relatif, distribusi, dan hubunganhubungan antar variabel sosiologis maupun psikologis. ${ }^{9}$ Peneliti mengedarkan kuesioner dan melakukan metode survei. ${ }^{10}$ Penelitian bertujuan menguji hipotesis yang menunjukkan pengaruh variabel bebas terhadap variabel terikat. Adapun yang menjadi variabel bebas adalah Ajaran Alkitab tentang Hakikat Kerja Berdasarkan Kolose 3:22-24; untuk selanjutnya akan diberi nama variable $\mathrm{X}$, selanjutnya yang menjadi variabel terikat adalah Etos Kerja; untuk selanjutnya akan diberi nama variabel $Y$.

Populasi dalam penelitian ini adalah jemaat GPdI Wlingi, Blitar, jemaat yang dijadikan obyek dalam penelitian ini sebanyak 70 responden ${ }^{11}$, dari total jemaat 225 orang (tidak termasuk anak-anak Sekolah Minggu). Dari jumlah tersebut ditetapkan

\footnotetext{
${ }^{6}$ Magdalena Lumbantoruan, “Abraham Maslow Hierarki Kebutuhan,” Ensiklopedi Nasional Indonesia Jilid 10 (PT Cipta Adi Pustaka Jakarta, 1990).

${ }^{7}$ Elisa Sari and Rina Dwiarti, "Pendekatan Hierarki Abraham Maslow Pada Prestasi Kerja Karyawan PT. Madubaru (PG Madukismo) Yogyakarta," Jurnal Perilaku dan Strategi Bisnis (2018).

${ }^{8}$ Sonny Eli Zaluchu, "Strategi Penelitian Kualitatif Dan Kuantitatif Di Dalam Penelitian Agama," Evangelikal: Jurnal Teologi Injili dan Pembinaan Warga Jemaat (2020).

${ }^{9}$ Sugiyono, Metode Penelitian Administrasi (Bandung: Penerbit Alfabeta, 2010), 7.

${ }^{10}$ Sugiyono, Metode Penelitian Pendidikan. Pendekatan Kuantitatif, Kualitatif, Dan R\&D (Bandung: Alfabeta, 2013).

${ }^{11}$ Andreas Subagyo, Pengantar Riset Kuantitatif dan Kualitatif (Bandung: Kalam Hidup, 2004), 225.
} 
30 orang untuk uji coba, sedangkan sisanya, 40 orang, untuk analisis data. Proses analisis data dilakukan dengan prosedur membuat deskripsi data penelitian; uji persyaratan analisis; dan uji hipotesis. Deskripsi penelitian bertujuan mengetahui gambaran data yang diperoleh, maka langkah pertama yang perlu dilakukan adalah melakukan deskripsi data penelitian. Selanjutnya dilakukan uji normalitas, untuk melihat apakah data memiliki distribusi normal sebagai syarat untuk melakukan uji statistik parametrik. Statistik parametris dipakai untuk menguji parameter populasi melalui statistik, atau menguji ukuran populasi melalui data sampel. ${ }^{12}$ Uji Normalitas dengan pendekatan estimasi proporsi dari Bloom melalui pendekatan P-P Plot pada grafik normal P-P Plot dan detrendednya.

Berikutnya, dilakukan uji linearitas, prasyarat untuk perhitungan statistik parametrik yang hendak melihat hubungan antar variabel. Uji linearitas dengan memperhatikan penyimpangan, dimana hubungan tersebut disebut linear jika terbukti signifikan pada $\alpha<0,05$. Jika didapati hubungan tidak linier, maka dilakukan perhitungan lanjut yaitu melalui estimasi kurve terhadap 11 jenis garis, di mana disebut linear jika signifikan pada $\alpha<0,05$. Langkah berikutnya adalah uji hipotesis dengan menggunakan statistik parametrik. Uji hipotesis pertama dan kedua dilakukan dengan confidence interval pada taraf signifikan 0,05. Peneliti menetapkan 3 kategori untuk setiap variabel. Adapun hipotesis ketiga dibuktikan melalui analisis korelasi sederhana, determinasi varians, uji signifikan korelasi sederhana, analisis regresi linear sederhana, dan clasification regression tree. Untuk menentukan sifat korelasi antar variabel digunakan kriteria sangat rendah $(0 \mathrm{~s} / \mathrm{d}$ 0.199), rendah $(0.2$ s/d 0.399), sedang (0.4 s/d 0.599), kuat (0.6 s/d 0.799) dan sangat kuat (0.8 s/d 1). ${ }^{13}$

\section{HASIL DAN PEMBAHASAN}

\section{Etos Kerja}

Semua orang Kristen adalah pekerja-pekerja, baik di dalam lingkup keluarga, masyarakat, organisasi atau gereja. Sebagai pekerja Kristen, orang Kristen harus mempunyai etos kerja yang baik. Etos kerja adalah pemahaman atas esensi kerja dengan mengenali motivasi yang sesungguhnya. ${ }^{14}$ Stela Timbuleng dan Jacky S. B. Sumarauw mengemukakan bahwa etos kerja adalah tindakan seseorang yang bersungguh-sungguh terhadap pekerjaan yang ia lakukan. ${ }^{15}$ Sahril dalam penelitian Rilfayanti Thomassawa mengatakan bahwa aplikasi dari etos kerja terlihat dalam bentuk keuletan, ketaatan, kreativitas, inovatif dan sikap altruistik. ${ }^{16}$ Priansa

\footnotetext{
${ }^{12}$ Sugiono, Metode Penelitian Pendidikan (Bandung: Alfabeta, 2010), 210.

${ }^{13}$ Ibid., 257.

${ }^{14}$ Sutjipto Subeno, “Etos Kerja Kristen (3),” 2011; Donni Juni Priansa, "Manajemen Kinerja Kepegawaian Dalam Pengelolaan SDM Perusahaan," in Cetakan Ke-1, 2017, 251-252.

${ }^{15}$ Jacky S. Sumarauw and Stela Timbuleng, "Etos Kerja, Disiplin Kerja, Dan Komitmen Organisasi Pengaruhnya Terhadap Kinerja Karyawan Pada PT Hasjrat Abadi Cabang Manado," Jurnal Riset Ekonomi, Manajemen, Bisnis dan Akuntansi (2015).

${ }^{16}$ Rilfayanti Thomassawa, "Pentingnya Motivasi Dalam Meningkatkan Etos Kerja Pegawai Dinas Pertanian Dan Perkebunan Kabupate Poso," Jurnal Ilmiah Administratie 7, no. 1 (2016).
} 
menyimpulkan etos kerja merupakan serangkaian prinsip dan nilai dalam merespon sesuatu hal secara khas di suatu komunitas yang memiliki kesamaan dalam keyakinan dan budaya. ${ }^{17}$ Andika Ardiansyah, Darwin Lie, Efendi, dan Andy Wijaya dalam penelitiannya berpendapat bahwa etos kerja merupakan serangkaian tindakan atau pandangan seseorang bahwa bekerja berdampak positif bagi penambahan kesejahteraan, dan ini berpengaruh pada sikap kerjanya. ${ }^{18}$ Penelitian Karauwan dan Mintardjo menunjukkan bahwa etos kerja secara simultan memiliki pengaruh yang positif dan signifikan terhadap kinerja seseorang. ${ }^{19}$ Sinamo mendefinisikan etos kerja sebagai serangkaian sikap kerja positif dan berkualitas tinggi, yang bersumber pada kesadaran yang jernih dan keyakinan yang kuat pada pola pikir kerja yang menyeluruh. ${ }^{20}$

Berdasarkan definisi-definisi di atas, maka peneliti menyimpulkan bahwa etos kerja adalah "totalitas unjuk kerja dan prestasi dalam perilaku kerja positif dan unggul sebagai ekspresi paradigma seseorang atau sekelompok orang terhadap makna kerja". Pemahaman yang kurang akan hakikat kerja akan berakibat pada etos kerja yang kurang baik. Sebaliknya, pemahaman dan pengertian akan arti hakikat kerja dari sudut pandang Alkitab akan membawa kesadaran dan perilaku etos kerja yang baik. Sejauh ini banyak pekerja Kristen; yang memiliki identitas sebagai garam dunia dan terang dunia belum menampakkan buahnya. Seorang pekerja Kristen seharusnya mempunyai etos kerja yang baik, hidup sejahtera dan menjadi teladan serta menjadi berkat bagi sesama, serta menjadi saksi Kristus melalui dunia kerjanya.

\section{Faktor-faktor yang Mempengaruhi Etos Kerja}

Etos kerja terkait erat dengan sistem budaya suatu komunitas; berupa hasil pemikiran mengenai sesuatu yang tertanam pada pola pikir mayoritas dari masyarakat yang dianggap bernilai, berharga, penting dalam hidup, sebagai nilai-nilai yang berlaku pada kelakuan, dan perbuatan dalam masyarakat. ${ }^{21}$ Setiap individu yang adalah peserta suatu budaya akan terikat kepada budaya di mana ia berada. Kekuatan sosial budaya mempengaruhi individu dalam dua sisi, positif dan negatif, jadi bisa menguntungkan atau merugikan. ${ }^{22}$ Penilaian masyarakat di suatu tempat terhadap makna kerja akan berpengaruh pada tinggi dan rendahnya etos kerja seseorang.

Faktor berikutnya adlaah kepemimpinan. Fungsi kepemimpinan menurut Siagian adalah sebagai penentu arah organisasi, sebagai juru bicara bagi pihak di luar

\footnotetext{
${ }^{17}$ Andika Ardiansyah; Darwin Lie; Efendi; Andy Wijaya, "Pengaruh Gaya Kepemimpinan Dan Etos Kerja Terhadap Kepuasan Kerja Karyawan Pada PT TASPEN (Persero) KC Pematangsiantar," Jurnal Maker 3, no. 2 (2017).

${ }^{18}$ Ibid.

${ }^{19}$ Raynald Karauwan and Victor P.K. Lengkong Christoffel Mintardjo, "Etos Kerja, Disiplin Kerja, Dan Komitmen Organisasi Pengaruhnya Terhadap Kinerja Karyawan Di Dinas Pekerjaan Umum Minahasa Selatan," Jurnal Riset Ekonomi, Manajemen, Bisnis dan Akuntansi (2015).

${ }^{20} J a n s e n$ Sinamo, 8 Etos Kerja Profesional (Jakarta: Institut Darma Mahardika, 2011).

${ }^{21}$ Masgaba, "Etos Kerja Komunitas Nelayan Pendatang Di Sodohoa Kendari Barat," Jurnal Pangadereng 5, no. 1 (2019).

${ }^{22}$ Yakob Tomatala, Antropologi. Dasar Pendekatan Pelayanan Lintas Budaya (Jakarta: YT Leadership Foundation, 2006).
} 
organisasi, sebagai komunikator yang baik, sebagai mediator yang trampil untuk mengatasi masalah internal, dan sebagai integrator yang rasional, efektif, obyektif dan netral. ${ }^{23}$ Munroe mengemukakan bahwa seorang pemimpin berpengaruh pada diri orang-orang yang dipimpinnya. Ia dapat mengubah seseorang dan mengembangkan potensi kepemimpinan di dalam diri orang tersebut. Seorang pemimpin sejati tidak mencari keuntungan untuk kepentingan dirinya sendiri. ${ }^{24}$ Penelitian Rismayanti, Ramadona, Mohammad menegaskan terdapat pengaruh kuat antara gaya kepemimpinan terhadap etos kerja seseorang. ${ }^{25}$ Kepemimpinan seseorang dalam sebuah organisasi sangat penting dan dapat mempengaruhi tingkat etos kerja orang yang dipimpinnya. Tingkat kedewasaan emosional dan kematangan berpikir serta kemampuan berkomunikasi yang efektif amat dibutuhkan dalam memotivasi dan membangun etos kerja yang tinggi bagi orang-orang yang dipimpinnya. ${ }^{26}$

Selanjutnya adalah ajaran agama. Weber berpendapat bahwa orang yang beriman kepada Allah ditandai oleh tanggungjawab yang optimal terhadap seluruh pekerjaan yang dipercayakan Tuhan kepadanya. Kerja adalah manifestasi dari ibadah. ${ }^{27}$ Alkitab mengatakan bahwa seorang pekerja Kristen harus bekerja dengan segenap hati untuk Tuhan (Kol 3:23), bukan pada manusia. ${ }^{28}$ Seorang yang percaya kepada Tuhan harus membuktikan diri melalui hasil pekerjaannya.

Kemudian, pendidikan. Etos kerja terkait erat dengan kualitas seseorang. Peningkatan kemampuan seseorang akan berdampak pada etos kerja keras. ${ }^{29}$ Rahimah, Fauziah, Suri dan Nasution dalam Ferry Novliadi menuliskan bahwa hal tersebut terjadi jika pendidikan diselenggarakan dengan disertai peningkatan dan perluasan pendidikan, keahlian dan keterampilan yang berakibat pada meningkatnya produktivitas masyarakat ${ }^{30}$ Otoriteit Dachi dan Delipiter Lase menemukan bahwa faktor yang berpengaruh dalam etos kerja hamba Tuhan, salah satunya adalah latar belakang pendidikan teologi. ${ }^{31}$ Pendidikan berperan penting sebagai pijakan seseorang untuk meningkatkan etos kerja yang berakibat pada kesejahteraan hidupnya.

Terakhir, motivasi. Tri Andjarwati mengatakan bahwa motivasi mempunyai pengaruh paling dominan bagi kinerja seseorang dibandingkan kepuasan kerja dan

\footnotetext{
${ }^{23}$ Sondang Siagian, Teori Dan Praktek Kepemimpinan (Jakarta: Penerbit Rineka Cipta, 2003).

${ }^{24}$ Myles Munroe, The Spirit of Leadership (Jakarta: Penerbit Immanuel, 2006).

${ }^{25}$ Rismayanti and Mohammad Ramadona, "Pengaruh Gaya Kepemimpinan Terhadap Etos Kerja Karyawan Pada PT. Pilar Adhi Pratama," JABE (Journal of Applied Business and Economic) (2019).

${ }^{26}$ Eddy Yunus, "Pengaruh Kompetensi Sumber Daya Manusia," Ekonomi dan Keuangan, no. 110 (2011): 1-16.

${ }^{27}$ Jansen Sinamo, 8 Etos Kerja Profesional (Jakarta: Institut Darma Mahardika, 2011),34

${ }^{28}$ Craig S. Keener, The IVP Bible Background Commentary - New Testament, 2nd ed. (Downer s Grove, Illionis: IVP Academic, 2014), 578.

${ }^{29}$ Anna Probowati, “Membangun Sikap Dan Etos Kerja," Segmen: Jurnal Manajemen dan Bisnis (2008).

${ }^{30}$ Ferry Novliadi, "Hubungan Antara Organization-Based Self-Esteem Dengan Etos Kerja," 2009.

${ }^{31}$ Otoriteit Dachi and Delipiter Lase, "Etos Kerja Pendeta BNKP," SUNDERMANN: Jurnal Ilmiah Teologi, Pendidikan, Sains, Humaniora dan Kebudayaan (2020).
} 
sistem penghargaan. ${ }^{32}$ Motivasi kerja adalah sesuatu yang menimbulkan semangat atau dorongan kerja. ${ }^{33}$ Drucker menuliskan bahwa motivasi berperan sebagai pendorong kemauan dan keinginan seseorang. Ini motivasi dasar seseorang untuk menggabungkan diri dengan organisasi dan berperan baik. ${ }^{34}$ Manullang berpendapat bahwa motivasi merupakan pekerjaan yang dilakukan oleh seorang manajer memberikan inspirasi, semangat dan dorongan kepada orang lain, dalam hal ini karyawan untuk mengambil tindakan-tindakan. Pemberian dorongan ini bertujuan untuk menggiatkan orang-orang karyawan agar mereka bersemangat dan dapat mencapai hasil sebagaimana dikehendaki dari orang-orang tersebut. ${ }^{35}$ Anoraga mengatakan bahwa individu yang memiliki Etos Kerja yang tinggi adalah individu yang bermotivasi tinggi. ${ }^{36}$

Dari hasil analisis Julian Wirano Deetje Silangen Lasut Ardjunius Tabaga, dinyatakan bahwa motivasi berpengaruh terhadap kinerja. ${ }^{37}$ Pernyataan ini diperkuat oleh Anak Kencanawati dalam penelitiannya bahwa motivasi seseorang berpengaruh dominan terhadap kinerjanya. ${ }^{38}$ Hasil penelitian Amelia Noviana, Ermi Girsang, dan Sri Wahyuni juga menunjukkan adanya pengaruh yang signifikan antara motivasi terhadap etos kerja. ${ }^{39}$ Demikian pula dengan Elisa Sari, dalam penelitiannya menekankan bahwa motivasi berdasarkan hierarki kebutuhan Maslow yang meliputi kebutuhan fisiologis, rasa aman, sosial, penghargaan, dan aktualisasi diri secara simultan mempunyai pengaruh yang signifikan terhadap prestasi kerja seseorang. ${ }^{40}$ Motivasi seseorang adalah kunci bagi etos kerjanya yang tinggi.

Di dalam dunia kerja, pekerja-pekerja Kristen seringkali diperhadapkan dengan berbagai permasalahan moral. Pekerja-pekerja Kristen harus tetap bisa mempertahankan etos kerja yang baik di dunia kerja masing-masing. Seorang pekerja Kristen semestinya mengerti hakikat kerja, supaya akan menyadari apa arti, peran, dan tujuan dirinya di dalam bekerja. Pekerja-pekerja Kristen sebagai garam dan terang dunia harus mampu memberi warna dan membawa Terang Kristus kepada

\footnotetext{
${ }^{32}$ Tri Andjarwati, “Motivasi Dari Sudut Pandang Teori Hirarki Kebutuhan Maslow," Jurnal Ilmu Ekonomi \& Manajemen (2015).

${ }^{33}$ Pandji Anoraga, Psikologi Kerja (Jakarta: Penerbit Rineka Cipta, 2006).

${ }^{34}$ Peter Drucker, Management Tasks, Responsibilities and Practice (Saduran PPM, Jakarta: Gramedia, 1983). Dalam Pandji Anoraga, Psikologi Kerja (Jakarta: Penerbit Rineka Cipta, 2006),38.

${ }^{35}$ M. Manullang \& Marihot AMH. Manullang, Manajemen Personalia (Yogyakarta: Gajahmada University Press, 2008).

${ }^{36}$ Anoraga, Psikologi, 37.

${ }^{37}$ Ardjunius Tabaga Julian Wirano, Deetje Silangen Lasut, "Pengaruh Motivasi Terhadap Kinerja Pustakawan Badan Perpustakaan Arsip Dan Dokumentasi Provinsi Sulawesi Utara," E-journal "Acta Diurna” IV, no. No.4 (2015).

${ }^{38}$ Anak Kencanawati, "Pengaruh Kepemimpinan, Etos Kerja, Motivasi Dan Disiplin Terhadap Kinerja Pegawai Kantor Pelayanan Pajak Madya Denpasar," Jurnal Bisnis dan Kewirausahaan (2013).

${ }^{39}$ Sri Wahyuni Nst. Amelia Noviana, Ermi Girsang, "Analisis Faktor-Faktor Yang Mempengaruhi Produktivitas Kinerja Bidan Di Ruang Kebidanan RSUD Raden Mattaher Jambi Tahun 2018," Scientia Journal 8, no. 1 (2019): 304-318.

${ }^{40}$ Sari and Dwiarti, "Pendekatan Hierarki Abraham Maslow Pada Prestasi Kerja Karyawan PT. Madubaru (PG Madukismo) Yogyakarta.” Jurnal Perilaku dan Strategi Bisnis. 2018.
} 
sesama melalui kehidupan mereka di mana pun mereka berada. Mereka harus memiliki etos kerja yang baik, sebab pekerja-pekerja Kristen adalah agen perubahan.

\section{Deskripsi Data}

Gambaran mengenai variabel Ajaran Alkitab tentang Hakikat Kerja Berdasarkan Kolose 3:22-24 (X) dan variabel Etos Kerja (Y) dipaparkan menggunakan statistik deskriptif yang meliputi perhitungan mean dan standard error of mean; median; standar deviasi; varians; nilai maksimum dan minimum; range; dan deskriptif inferensial melalui kecenderungan gambaran sampel pada setiap variabel terhadap kecenderungan populasi melalui confidence interval pada taraf signifikansi 0,05. Juga disajikan distribusi data dalam bentuk histogram.

\section{Variabel Etos Kerja (Y)}

Dari hasil penelitian terhadap 30 orang responden diperoleh hasil untuk: ratarata (mean) sebesar 56.48; titik tengah (median) sebesar 56; nilai yang sering muncul (mode) sebesar 65; simpangan baku (standar deviasi) sebesar 6.500; rentangan (range) sebesar 26; skor minimum dari data (minimum) sebesar 39 dan skor maksimum dari data (maximum) sebesar 65. Gambaran lengkap deskripsi data variabel termasuk distribusi frekuensi dan histogram dapat dilihat pada Lampiran 1.

\section{Variabel Ajaran Hakikat Kerja Menurut Kolose 3:22-24 (X)}

Dari hasil penelitian terhadap 30 orang responden diperoleh hasil untuk: ratarata (mean) sebesar 50.38; titik tengah (median) sebesar 52; nilai yang sering muncul (mode) sebesar 55; simpangan baku (standar deviasi) sebesar 7.980; rentangan (range) sebesar 39; skor minimum dari data (minimum) sebesar 26 dan skor maksimum dari data (maximun) sebesar 65. Gambaran lengkap deskripsi data variabel termasuk distribusifrekuensi dan histogram dapat dilihat pada Lampiran 1.

Tabel 1. Tabulasi Deskripsi Data Responden variabel Y dan X

\begin{tabular}{ccccccccc}
\hline Var & Data & Mean & Median & Mode & Std Dev & Range & Min & Max \\
\hline $\mathrm{Y}$ & 30 & 56.48 & 56 & 65 & 6.500 & 26 & 39 & 65 \\
\hline $\mathrm{X}$ & 30 & 50.38 & 52 & 55 & 7.980 & 39 & 26 & 65 \\
\hline
\end{tabular}

\section{Uji Normalitas}

Uji Normalitas dilakukan dengan menggunakan estimasi proporsi dari Rumus Bloom dengan pendekatan P-P Plot, pengamatan dilakukan pada grafik normal P-P Plot dan detrended normal P-P Plot. Hasil uji normalitas data selengkapnya dapat diamati pada Lampiran 2 dan pengamatan dilakukan pada grafik normal P-P Plot dan detrended normal P-P Plot.

\section{Variabel Etos Kerja (Y)}

Untuk data yang berdistribusi normal, pengamatan pada grafik normal P-P Plot memperlihatkan sebaran data disekitar garis normal. Adapun grafik normal P-P Plot dari data seperti gambar berikut ini. 


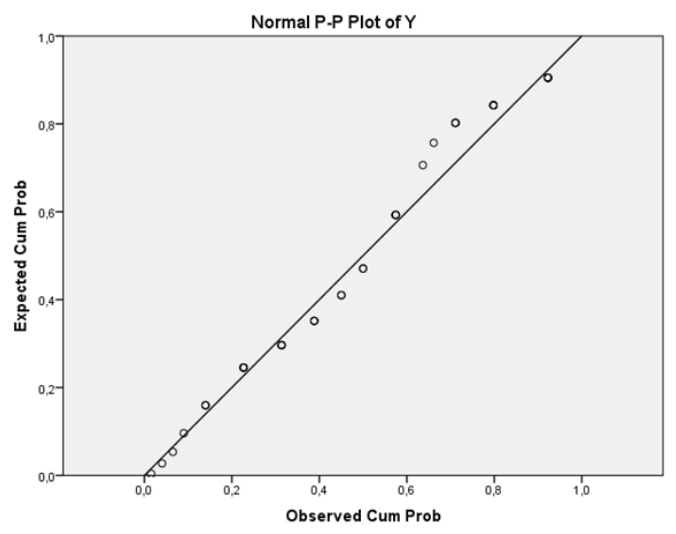

Sedangkan grafik detrended normal P-P Plot dari data diperlihatkan dalam gambar di bawah ini.

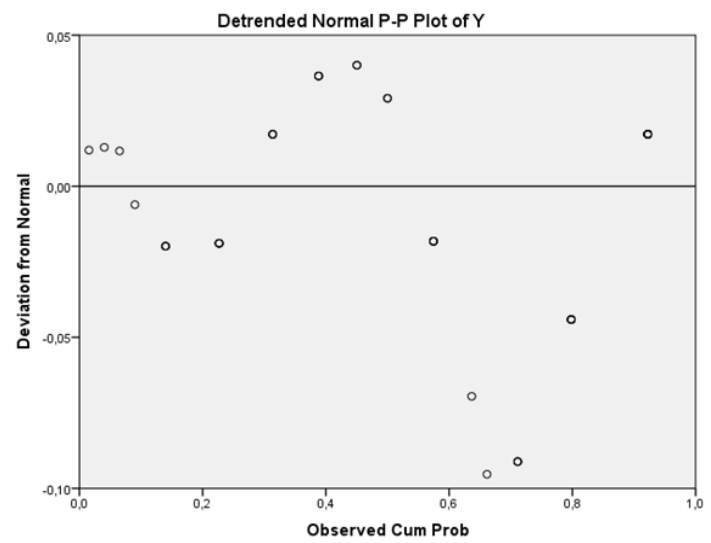

Sesuai dengan output yang dihasilkan (Lihat Lampiran 2), maka grafik P-P Plot variabel Etos Kerja memperlihatkan sebaran data di sekitar garis normal. Terlihat pula pada grafik detrended normal P-P Plot bahwa sebaran data variabel tidak memperlihatkan pola tertentu. Dengan demikian disimpulkan bahwa variabel Etos Kerja memiliki distribusi normal atau dianggap berdistribusi normal.

\section{Variabel Hakikat Kerja Menurut Kolose 3:22-24 (X)}

Untuk data yang berdistribusi normal, pengamatan pada grafik normal P-P Plot memperlihatkan sebaran data disekitar garis normal. Adapun grafik normal P-P Plot dari data seperti gambar berikut ini.

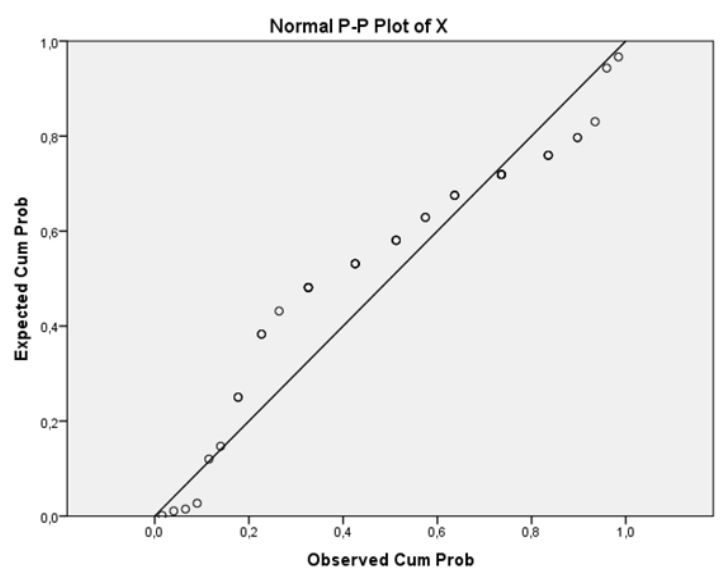


Sedangkan grafik detrended normal P-P Plot dari data diperlihatkan dalam gambar di bawah ini.

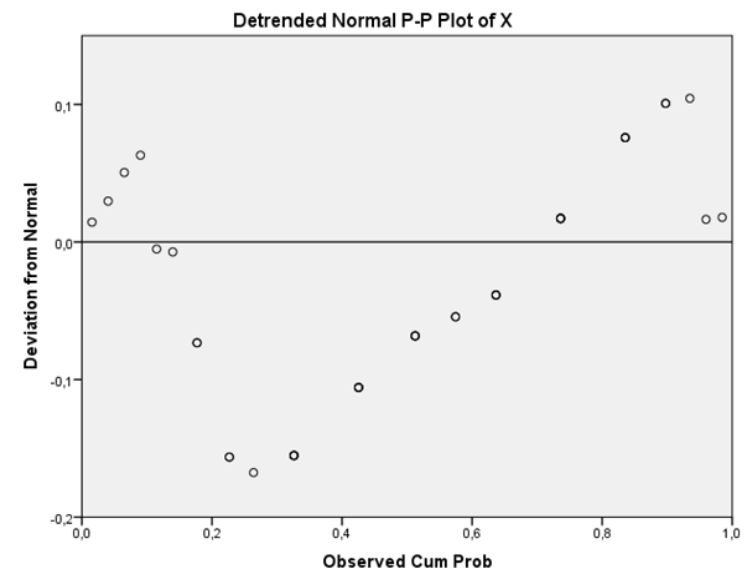

Sesuai dengan output yang dihasilkan (Lihat Lampiran 2), maka grafik P-P Plot variabel Ajaran Hakikat Kerja Berdasarkan Kolose 3:22-24 memperlihatkan sebaran data disekitar garis normal. ${ }^{41}$ Terlihat pula pada grafik detrended normal P-P Plot bahwa sebaran data variabel tidak memperlihatkan pola tertentu. Dengan demikian disimpulkan bahwa variabel Etos Kerja memiliki distribusi normal atau dianggap berdistribusi normal.

\section{Uji Linieritas}

Uji linearitas garis regresi adalah syarat untuk menggunakan model regresi linear sederhana dalam pengujian hipotesis. Pengujian ini perlu dilakukan agar hasil analisis yang diperoleh dapat dipertanggungjawabkan dalam pengambilan kesimpulan penelitian dalam kaitannya dengan hubungan antar variabel baik di sampel maupun pengaruhnya di populasi. Kaidah pengambilan keputusan linearitas adalah melihat probabilitas pada taraf signifikansi. Data dianggap linier jika memenuhi nilai signifikansi yang $>$ dari 0,05. Jika hal tersebut tidak terpenuhi maka data akan diuji melalui estimasi kurva, bila diperoleh nilai Sig $<0,05$ pada baris linier, maka data berpola linier atau dianggap berpola linier. ${ }^{42}$ Berdasarkan hasil perhitungan linearitas variabel X terhadap Y diperoleh hasil seperti dilaporkan dalam tabel berikut ini, artinya signifikan pada $\alpha>0,05$ sehingga tidak perlu dilanjutkan dengan perhitungan estimasi kurva.

Tabel 2. Data Tes Linieritas Dimensi Variabel X terhadap Variabel Y

\begin{tabular}{ccccc}
\hline $\begin{array}{c}\text { Variabel Y } \\
\text { atas: }\end{array}$ & F & Sig & Keterangan & Kesimpulan \\
\hline $\mathrm{X}$ & 1.694 & 0,125 & $\alpha>0,05$ & Linear \\
\hline
\end{tabular}

\footnotetext{
${ }^{41}$ Sonny Eli Zaluchu, Sistematika Riset Dan Analisis Data Kuantitatif (Semarang: Golden Gate Publishing, 2018), 69.

${ }^{42}$ Zaluchu, Sistematika Riset Dan Analisis Data Kuantitatif.
} 
Dengan demikian, setelah melalui tahap uji normalitas data dan linearitas data, terbukti bahwa distribusi data normal dan memperlihatkan pola linier, sehingga perhitungan dapat dilanjutkan pada uji hipotesis menggunakan analisis korelasi dan regresi.

\section{Pengujian Hipotesis dan Pembahasan Uji Hipotesis Pertama}

Hipotesis pertama: tingkat pemahaman jemaat GPdI Wlingi, Blitar mengenai ajaran Alkitab tentang hakikat kerja berdasarkan Kolose 3:22-24 adalah sedang. Dari hasil uji statistik deskriptif terhadap variabel Ajaran Alkitab tentang Hakikat Kerja Berdasarkan Kolose 3:22-24 (X) diperoleh hasil seperti tabel berikut ini. Jumlah klas ( $\mathrm{k}$ ) ditetapkan 3 yakni kurang memahami, cukup memahami dan sangat memahami. Interval klas $i_{k}=$ Range $/ \Sigma \mathrm{k}$ diperoleh nilai 13. Hasil perhitungan lengkapnya dapat dilihat pada Lampiran 4.

Tabel 3. Hasil Uji Statistik Deskriptif Pemahaman Jemaat mengenai Ajaran Alkitab tentang Hakikat Kerja Berdasarkan Kolose 3:22-24

\begin{tabular}{ccc}
\hline $\begin{array}{c}\text { Klas } \\
\text { Interval }\end{array}$ & $\begin{array}{c}\text { Keterangan } \\
\text { Klas }\end{array}$ & $\begin{array}{c}\text { Nilai } \\
\text { Lower-Upper Bound }\end{array}$ \\
\hline $25-38$ & Kurang Memahami & \\
\hline $\mathbf{3 9 - 5 2}$ & Cukup Memahami & $\mathbf{4 7 . 8 2}$ s/d 52.93 \\
\hline $53-66$ & Sangat Memahami & \\
\hline
\end{tabular}

Dari perhitungan di atas dapat disimpulkan bahwa rentang nilai Lower Bound dan Upper Bound yakni 47.82 s/d 52.93 terletak pada kategori cukup memahami di dalam tabel klas interval. Artinya, pemahaman jemaat GPdI Wlingi, Blitar mengenai Ajaran Alkitab tentang Hakikat Kerja Berdasarkan Kolose 3:22-24 adalah dalam kategori cukup memahami.

Hasil tersebut di atas memperlihatkan bahwa level pemahaman jemaat mengenai ajaran Alkitab tentang Hakikat Kerja Berdasarkan Kolose 3:22-24 masih perlu ditingkatkan lagi karena berada di dalam kategori sedang dan Bound yang cenderung bergerak ke interval diatasnya. Dengan demikian dapat disimpulkan bahwa sekalipun ditemukan pemahaman jemaat dalam kategori cukup memahami, sebetulnya hal berpeluang untuk naik dengan memperhatikan nilai Upper ini masih dapat ditingkatkan lagi menuju kategori sangat memahami.

\section{Uji Hipotesis Kedua}

Hipotesis kedua: tingkat etos kerja jemaat GPdI Wlingi, Blitar adalah sedang. Dari hasil uji statistik deskriptif terhadap variabel Etos Kerja (Y) diperoleh hasil seperti tabel berikut ini. Jumlah klas $(\Sigma \mathrm{k})$ ditetapkan 3 yakni rendah, cukup dan tinggi. Interval klas $\mathrm{i}_{\mathrm{k}}=$ Range $/ \Sigma \mathrm{k}$ diperoleh nilai 8.6 dan dibulatkan 8. Hasil perhitungan lengkapnya dapat dilihat pada Lampiran 5. 
Tabel 4. Hasil Uji Statistik Deskriptif tingkat Etos Kerja

\begin{tabular}{ccc}
\hline $\begin{array}{c}\text { Klas } \\
\text { Interval }\end{array}$ & $\begin{array}{c}\text { Keterangan } \\
\text { Klas }\end{array}$ & $\begin{array}{c}\text { Nilai } \\
\text { Lower-Upper Bound }\end{array}$ \\
\hline $39-47$ & Rendah & \\
\hline $\mathbf{4 8 - 5 6}$ & Sedang & $\mathbf{5 4 . 4 0 ~ s / d ~}$ \\
\hline $\mathbf{5 7 - 6 5}$ & Tinggi & $\mathbf{5 8 . 5 5}$ \\
\hline
\end{tabular}

Dari perhitungan di atas dapat disimpulkan bahwa rentang nilai Lower Bound dan Upper Bound yakni 54.40 s/d 58.55 terletak pada kategori sedang menuju tinggi di dalam tabel klas interval. Artinya, tingkat Etos Kerja di kalangan jemaat GPdI Wlingi, Blitar cenderung bergerak menuju tinggi. Hal ini menjelaskan fakta bahwa sebagian besar jemaat adalah kelas pekerja dengan etos kerja yang sangat baik. Aspek-aspek yang mendukung atau mempengaruhi etos kerja tersebut akan diuji dalam hipotesis ketiga melalui variabel yang telah ditetapkan dalam model penelitian yakni Pemahaman Jemaat tentang Ajaran Alkitab tentang Hakikat Kerja Berdasarkan Kolose 3:22-24.

\section{Uji Hipotesis Ketiga}

Hipotesis ketiga: ada pengaruh antara ajaran tentang hakikat kerja menurut Kolose 3:22-24 terhadap etos kerja jemaat GPdI Wlingi, Blitar. Dari hasil uji statistik regresi sederhana antara variable Ajaran Alkitab tentang Hakikat Kerja Berdasarkan Kolose 3:22-24 (X) terhadap variabel Etos Kerja (Y) diperoleh hasil seperti tabel di bawah ini. Hasil perhitungan lengkapnya dapat dilihat pada Lampiran 6.

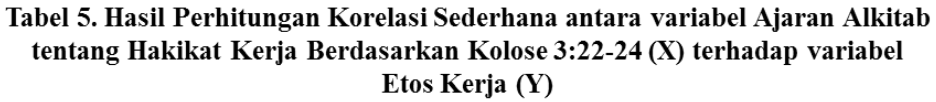

\begin{tabular}{lcccc}
\hline Model & R & R Square & $\begin{array}{c}\text { Adjusted R } \\
\text { Square }\end{array}$ & $\begin{array}{c}\text { Std. Error of the } \\
\text { Estimate }\end{array}$ \\
\hline 1 &, $454^{\mathrm{a}}$ &, 206 &, 185 & 5,869 \\
\hline $\begin{array}{l}\text { a. Predictors: (Constant), } \mathrm{X} \\
\text { b. Dependent Variable: Y }\end{array}$ & & \\
\end{tabular}

Berdasarkan tabel di atas, ditemukan nilai $r$ xy sebesar 0,454 dan bernilai positif. Yang berarti, besarnya hubungan antara Ajaran Alkitab tentang Hakikat Kerja Berdasarkan Kolose 3:22-24 (X) terhadap Etos Kerja (Y) adalah 0,454 atau termasuk dalam kategori korelasi yang sedang. Arah hubungan keduanya adalah positif, yang memperlihatkan bahwa semakin tinggi pemahaman tentang Ajaran Alkitab tentang Hakikat Kerja Berdasarkan Kolose 3:22-24 di dalam diri seseorang akan membuat Etos Kerjanya cenderung meningkat. Demikian pula sebaliknya.

Dari hasil analisis juga diperoleh nilai $\mathrm{r}_{\mathrm{xy}}{ }^{2}$ (koefisien determinasi) sebesar 0,185 atau 18,5\% . Artinya sumbangan variabel Ajaran Alkitab tentang Hakikat Kerja Berdasarkan Kolose 3:22-24 dalam membentuk variabel Etos Kerja di kalangan jemaat GPdI Wlingi, Blitar adalah 18,5\% sedangkan sisanya sebesar 81,5\% dijelaskan oleh sebab-sebab lain di luar model penelitian. 
Uji signifikansi Regresi antara variabel Ajaran Alkitab tentang Hakikat Kerja Berdasarkan Kolose 3:22-24 (X) terhadap variabel Etos Kerja (Y) dijelaskan di dalam tabel di bawah ini.

Tabel 6. Uji Signifikansi Regresi antara variabel Ajaran Alkitab tentang Hakikat Kerja Berdasarkan Kolose 3:22-24 (X) terhadap variabel Etos Kerja (Y)

ANOVA $^{b}$

\begin{tabular}{ccccccc}
\hline & & Sum of & \multicolumn{3}{c}{ Mean } \\
Model & Squares & Df & Square & F & Sig. \\
\hline \multirow{3}{*}{1} & Regression & 339,254 & 1 & 339,254 & 9,851 & \multirow{2}{*}{$003^{\text {a }}$} \\
& & & & & & \\
\cline { 2 - 7 } & Residual & 1308,721 & 38 & 34,440 & & \\
\cline { 2 - 7 } & Total & 1647,975 & 39 & & & \\
\hline
\end{tabular}

a. Predictors: (Constant), $\mathrm{X}$ tot

b. Dependent Variable: Y tot

Berdasarkan tabel di atas dihasilkan F sebesar 9.851 yang ternyata signifikan pada $\alpha<0.01$. Oleh karena, $\alpha=0,003$ itu berarti $<$ dari 0,01 , maka dapat ditarik kesimpulan bahwa hubungan pemahaman jemaat tentang Ajaran Alkitab tentang Hakikat Kerja Berdasarkan Kolose 3:22-24 terhadap variabel Etos Kerja di kalangan jemaat GPdI Wlingi Blitar adalah signifikan.

\begin{tabular}{|c|c|c|c|c|c|c|c|c|}
\hline \multirow{3}{*}{\multicolumn{2}{|c|}{ Model }} & \multicolumn{5}{|c|}{ Coefficients a } & & \\
\hline & & \multicolumn{2}{|c|}{$\begin{array}{c}\text { Unstandardized } \\
\text { Coefficients }\end{array}$} & \multirow{2}{*}{$\begin{array}{c}\text { Standardized } \\
\text { Coefficients }\end{array}$} & \multirow[b]{2}{*}{$\mathbf{T}$} & \multirow[b]{2}{*}{ Sig. } & \multicolumn{2}{|c|}{$\begin{array}{c}95,0 \% \\
\text { Confidence } \\
\text { Interval for B } \\
\end{array}$} \\
\hline & & B & Std. Error & & & & $\begin{array}{l}\text { Lower } \\
\text { Bound } \\
\end{array}$ & $\begin{array}{l}\text { Upper } \\
\text { Bound }\end{array}$ \\
\hline \multirow[t]{2}{*}{1} & (Constant) & 37,856 & 6,004 & & 6,305 &, 000 & 25,701 & 50,011 \\
\hline & $\mathrm{X}$ &, 370 & ,118 &, 454 & 3,139 &, 003 &, 131 & ,608 \\
\hline
\end{tabular}

a. Dependent Variable: Y

Jika dilihat dari populasi, diperoleh nilai t sebesar 3,139 dan ternyata signifikan pada $\alpha<0,01$. Berarti, variabel Ajaran Alkitab tentang Hakikat Kerja menurut Kolose 3:22 $24(\mathrm{X})$ berpengaruh terhadap variabel Etos Kerja (Y). Adapun persamaan garis regresi linier dihasilkan $\hat{Y}=37.856+0.370 \mathrm{X}$. Artinya, setiap terjadi perbaikan satu kali pemahaman jemaat GPdI Wlingi, Blitar dalam hal Ajaran Alkitab tentang Hakikat Kerja Berdasarkan Kolose 3:22-24, maka Etos Kerja jemaat akan meningkat 0.370 kali.

Selanjutnya, berdasarkan hasil analisis pengujian pengaruh langsung dan tidak langsung latar belakang jemaat yang dominan mempengaruhi variabel Etos Kerja (Y), maka diperoleh hasil sebagai berikut. Pengujian dilakukan menggunakan analisis classification and regression tree yang menguji secara serentak terhadap variabel Etos Kerja (Y) empat aspek latar belakang yakni umur, lama berjemaat, tingkat pendidikan dan jenis pekerjaan. Hasil perhitungan lengkapnya dapat dilihat pada Lampiran 7. 


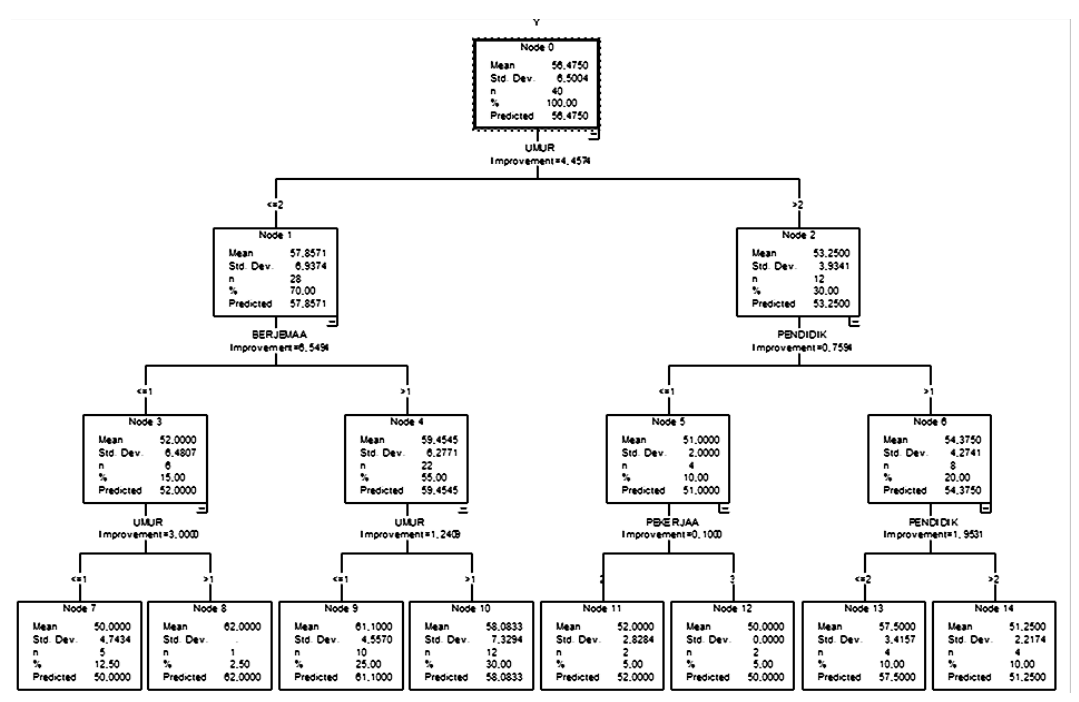

Dari hasil analisis diatas terlihat bahwa aspek latar belakang Umur Jemaat adalah dominan dalam mempengaruhi Etos Kerja. Artinya, makin dewasa umur jemaat akan membawa dampak membaiknya etos kerja, dimana latar belakang Umur Jemaat terbukti mampu memperbaiki 4.4574 kali peningkatan Etos Kerja di kalangan Jemaat GPdI Wlingi, Blitar dari kondisi yang ada sekarang.

Secara visual hasil perhitungan di atas dapat dinyatakan di dalam gambar di bawah ini.

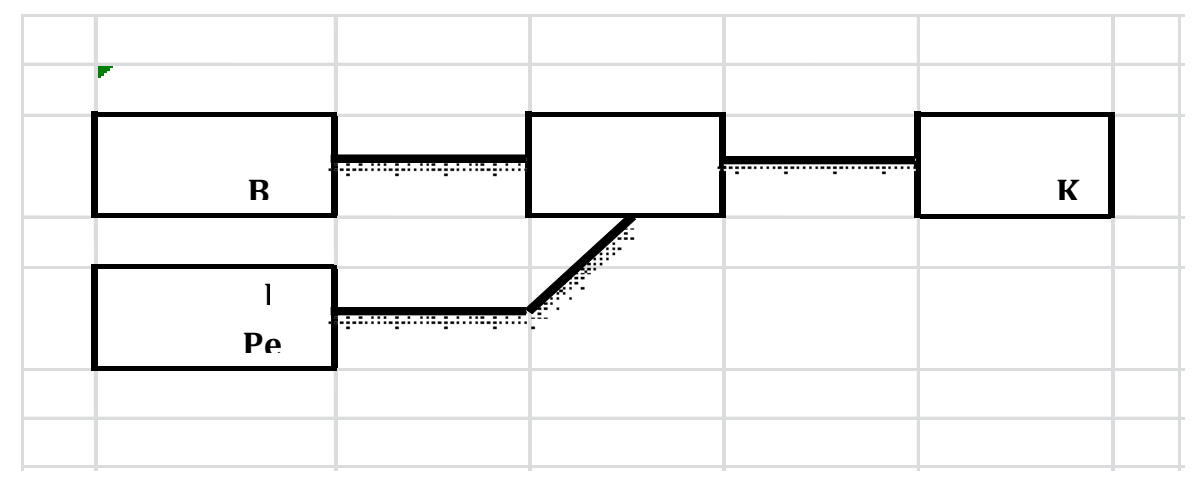

Berdasarkan proyeksi visual di atas terlihat bahwa untuk meningkatkan etos kerja jemaat di GPdI Wlingi, Blitar, dibutuhkan jemaat dengan tingkat usia dewasa. Aspek Umur Jemaat yang mempengaruhi Etos Kerja ini ikut dipengaruhi oleh sejauh jemaat dewasa tersebut tertanam sebagai jemaat lokal yang ditandai dengan aspek lama berjemaat. Artinya, semakin lama berjemaat, akan membuat usia biologis jemaat bertambah dewasa dan hal ini membawa dampak pada peningkatan etos kerjanya.

\section{KESIMPULAN}

Pemahaman jemaat GPdI Wlingi, Blitar mengenai ajaran Alkitab tentang hakikat kerja berdasarkan Kolose 3:22-24 adalah sedang. Hal tersebut ditandai dengan rentang nilai Lower Bound dan Upper Bound yakni 47.82 s/d 52.93 terletak pada kategori cukup memahami di dalam tabel klas interval. Tingkat Etos Kerja di kalangan jemaat GPdI Wlingi, Blitar cenderung bergerak dari sedang menuju tinggi. Hal tersebut ditandai dengan rentang nilai Lower Bound dan Upper Bound yakni 54.40 
s/d 58.55 terletak pada kategori sedang menuju tinggi di dalam tabel klas interval. Hal ini menjelaskan fakta bahwa sebagian besar jemaat adalah kelas pekerja dengan etos kerja yang tinggi. Besarnya pengaruh variabel Ajaran Alkitab tentang Hakikat

Kerja Berdasarkan Kolose 3:22-24 terhadap variabel Etos Kerja di kalangan jemaat GPdI Wlingi, Blitar adalah 18,5\%. Sedangkan sisanya sebesar 81,5\% dijelaskan oleh sebab-sebab lain di luar model penelitian ini. Ajaran Alkitab tentang hakikat kerja menurut Kolose 3:22-24 harus diajarkan dan diimplementasikan di semua gereja untuk meningkatkan etos kerja jemaatnya, supaya jemaat mengalami kesejahteraan secara jasmani dan rohani.

\section{REFERENSI}

Amelia Noviana, Ermi Girsang, Sri Wahyuni Nst. “Analisis Faktor-Faktor Yang Mempengaruhi Produktivitas Kinerja Bidan Di Ruang Kebidanan RSUD Raden Mattaher Jambi Tahun 2018." Scientia Journal 8, no. 1 (2019): 304-318.

Andika Ardiansyah; Darwin Lie; Efendi; Andy Wijaya. "Pengaruh Gaya Kepemimpinan Dan Etos Kerja Terhadap Kepuasan Kerja Karyawan Pada PT TASPEN (Persero) KC Pematangsiantar." Jurnal Maker 3, no. 2 (2017).

Andjarwati, Tri. "Motivasi Dari Sudut Pandang Teori Hirarki Kebutuhan Maslow,." Jurnal Ilmu Ekonomi \& Manajemen (2015).

Anoraga, Pandji. Psikologi Kerja. Jakarta: Penerbit Rineka Cipta, 2006.

Arsyianti, Laily Dwi. "Zakat Dan Kemiskinan Multidimensi." Republika Online, 2014.

Bambangan, Malik. "Perspektif Teologis Terhadap Etika Bisnis Kristen." JURNAL LUXNOS (2019).

Dachi, Otoriteit, and Delipiter Lase. "Etos Kerja Pendeta BNKP." SUNDERMANN: Jurnal Ilmiah Teologi, Pendidikan, Sains, Humaniora dan Kebudayaan (2020).

Julian Wirano, Deetje Silangen Lasut, Ardjunius Tabaga. "Pengaruh Motivasi Terhadap Kinerja Pustakawan Badan Perpustakaan Arsip Dan Dokumentasi Provinsi Sulawesi Utara." E-journal "Acta Diurna" IV, no. No.4 (2015).

Karauwan, Raynald, and Victor P.K. Lengkong Christoffel Mintardjo. "Etos Kerja, Disiplin Kerja, Dan Komitmen Organisasi Pengaruhnya Terhadap Kinerja Karyawan Di Dinas Pekerjaan Umum Minahasa Selatan." Jurnal Riset Ekonomi, Manajemen, Bisnis dan Akuntansi (2015).

Keener, Craig S. The IVP Bible Background Commentary - New Testament. 2nd ed. Downer s Grove, Illionis: IVP Academic, 2014.

Kencanawati, Anak. "Pengaruh Kepemimpinan, Etos Kerja, Motivasi Dan Disiplin Terhadap Kinerja Pegawai Kantor Pelayanan Pajak Madya Denpasar." Jurnal Bisnis dan Kewirausahaan (2013).

Magdalena Lumbantoruan. "Abraham Maslow Hierarki Kebutuhan.” Ensiklopedi Nasional Indonesia Jilid 10. PT Cipta Adi Pustaka Jakarta, 1990.

Manullang, M. Manullang \& Marihot AMH. Manajemen Personalia. Yogyakarta: Gajahmada University Press, 2008.

Masgaba. "Etos Kerja Komunitas Nelayan Pendatang Di Sodohoa Kendari Barat." Jurnal Pangadereng 5, no. 1 (2019).

Mualifah, Nur. "Dampak Kemiskinan Terhadap Kesejahteraan Masyarakat Kampung Bumi Raharjo Dalam Prespektif Ekonomi Islam." IAIN METRO (2019).

Munroe, Myles. The Spirit of Leadership. Jakarta: Penerbit Immanuel, 2006. 
Nadjib, Mochammad. “Agama, Etika Dan Etos Kerja Dalam Aktivitas Ekonomi Masyarakat Nelayan Jawa.” Jurnal Ekonomi dan Pembangunan (2013).

Novliadi, Ferry. "Hubungan Antara Organization-Based Self-Esteem Dengan Etos Kerja," 2009.

Nur, Hikma. "Aspek Psikologis Tokoh Dalam Novel Sepatu Dahlan Karya Khrisna Pabichara (Kajian Psikologi Humanistik Abraham Maslow)." Jurnal humanika (2015).

Priansa, Donni Juni. “Manajemen Kinerja Kepegawaian Dalam Pengelolaan SDM Perusahaan." In Cetakan Ke-1, 251-252, 2017.

Probowati, Anna. "Membangun Sikap Dan Etos Kerja." Segmen: Jurnal Manajemen dan Bisnis (2008).

Rismayanti, and Mohammad Ramadona. "Pengaruh Gaya Kepemimpinan Terhadap Etos Kerja Karyawan Pada PT. Pilar Adhi Pratama." JABE (Journal of Applied Business and Economic) (2019).

Sari, Elisa, and Rina Dwiarti. "Pendekatan Hierarki Abraham Maslow Pada Prestasi Kerja Karyawan PT. Madubaru (PG Madukismo) Yogyakarta.” Jurnal Perilaku dan Strategi Bisnis (2018).

Sasmito, Eko. "Work Spirit," 2011.

Siagian, Sondang. Teori Dan Praktek Kepemimpinan. Jakarta: Penerbit Rineka Cipta, 2003.

Sinamo, Jansen. 8 Etos Kerja Profesional. Jakarta: Institut Darma Mahardika, 2011.

Subeno, Sutjipto. "Etos Kerja Kristen (3)," 2011.

Sugiyono. Metode Penelitian Pendidikan. Pendekatan Kuantitatif, Kualitatif, Dan R\&D. Bandung: Alfabeta, 2013.

Sumarauw, Jacky S., and Stela Timbuleng. "Etos Kerja, Disiplin Kerja, Dan Komitmen Organisasi Pengaruhnya Terhadap Kinerja Karyawan Pada PT Hasjrat Abadi Cabang Manado." Jurnal Riset Ekonomi, Manajemen, Bisnis dan Akuntansi (2015).

Thomassawa, Rilfayanti. "Pentingnya Motivasi Dalam Meningkatkan Etos Kerja Pegawai Dinas Pertanian Dan Perkebunan Kabupate Poso." Jurnal Ilmiah Administratie 7, no. 1 (2016).

Tomatala, Yakob. Antropologi. Dasar Pendekatan Pelayanan Lintas Budaya. Jakarta: YT Leadership Foundation, 2006.

Yunus, Eddy. "Pengaruh Kompetensi Sumber Daya Manusia." Ekonomi dan Keuangan, no. 110 (2011): 1-16.

Zaluchu, Sonny Eli. Sistematika Riset Dan Analisis Data Kuantitatif. Semarang: Golden Gate Publishing, 2018.

-_- "Strategi Penelitian Kualitatif Dan Kuantitatif Di Dalam Penelitian Agama." Evangelikal: Jurnal Teologi Injili dan Pembinaan Warga Jemaat (2020). 